\title{
Chapter 5 \\ Nuclear Deterrence: A Guarantee \\ for or Threat to Strategic Stability?
}

\author{
Alexey Arbatov
}

\section{Contents}

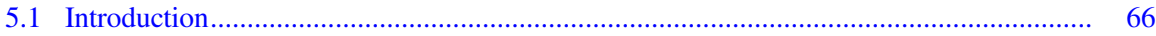

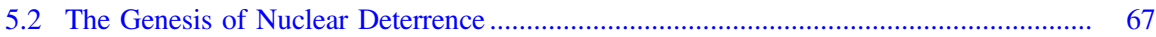

5.3 The Birth of the Concept of Strategic Stability........................................................... 68

5.4 Modern Nuclear Doctrines .............................................................................................. 71

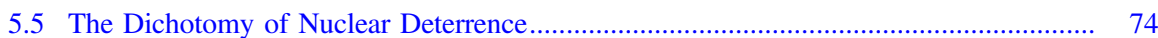

5.6 The Collapse of Nuclear Arms Control .............................................................. 79

5.7 Renewing Strategic Stability and Arms Control ............................................................ 80

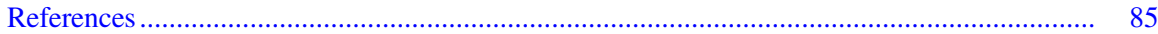

\begin{abstract}
In recent literature, much attention has been paid to factors that affect nuclear deterrence and stability from the outside: new missile defence systems, non-nuclear (conventional) high-precision long-range weapons, the influence of third and threshold nuclear states, space weapons, and-more recently-cyber threats. These new factors have pushed the core of nuclear deterrence-strategic relations between Russia and the United States - to the background in the public consciousness. Yet dangerous changes are taking place. This chapter examines the real and imaginary causes of the current situation and suggests potential ways to reduce tensions that could benefit international security. It concludes that nuclear deterrence can serve as a pillar of international security with one crucial reservation: namely, that it can only work in conjunction with negotiations and agreements on
\end{abstract}

This chapter is a slightly revised version of Alexey Arbatov, Nuclear Deterrence: A Guarantee or Threat to Strategic Stability?, Carnegie Foundation, Moscow, 22 March 2019. Reprinted with permission.

\footnotetext{
A. Arbatov ( $\bowtie)$

Center for International Security, Primakov National Research Institute of World Economy and International Relations (IMEMO), Moscow, Russia

e-mail: info@carnegie.ru

(C) The Author(s) 2021

F. Osinga and T. Sweijs (eds.), NL ARMS Netherlands Annual Review

of Military Studies 2020, NL ARMS, https://doi.org/10.1007/978-94-6265-419-8_5
} 
the limitation, reduction, and non-proliferation of nuclear weapons. Without such checks, nuclear deterrence goes berserk. It endlessly fuels the arms race, brings the great powers to the brink of nuclear war in any serious crisis, and sometimes the very dynamics of nuclear deterrence can instigate a confrontation.

Keywords Arms control - Strategic stability - Arms race - Nuclear doctrines • START

\subsection{Introduction}

The United States' withdrawal from the 1987 Intermediate-Range Nuclear Forces (INF) Treaty and the growing likelihood of the termination of the $2010 \mathrm{New}$ Strategic Arms Reduction Treaty (New START) are returning U.S.-Russia nuclear issues to the forefront of discussions on international security and geopolitics. In these discussions, it is difficult to find concepts that are more commonly used-and abused - than strategic stability and nuclear deterrence. Both concepts have a long history. The former has been in official use for nearly thirty years, while the latter has been around for almost seventy. They appear in many state documents and international agreements. Entire libraries of academic literature and propaganda have been written about them, not to mention the reams devoted to both concepts on the Internet, along with oceans of words at countless conferences and symposiums.

Nevertheless, these concepts, their dynamics, and their dialectical interrelationship create new problems time and again. They give rise to paradoxes that, were it not a life-and-death matter for modern civilization, could be considered intellectually fascinating. But, unfortunately, these concepts concern actual matters of life and death. In the current military and political environment, it is no longer inconceivable that war between the United States and Russia could break out in just a few days in the event of a crisis. Such a conflict might culminate with an exchange of nuclear strikes taking as long as just a few hours.

During those hours, hundreds of millions of people in the northern hemisphere would be killed, and everything created by human civilization in the last thousand years would be destroyed. The direct effects would be irreversible, and the secondary effects would likely kill the rest of the world's population within a number of years, or at least send the remaining population back into a prehistoric existence. The prevention of nuclear war is an indispensable condition for the survival of human civilization, and it is inextricably linked to the concepts of nuclear deterrence, strategic stability, nuclear disarmament, and non-proliferation. It might seem that all of the above goes without saying, and that all of this has long been accepted both in theory and practice by politicians, military leaders, civilian experts, and the enlightened public of the world's advanced nations. Over the past three decades, the nuclear arsenals of Russia and the United States have been reduced substantiallyboth in terms of the number of warheads and in terms of total destructive power. 
Yet despite all of this, the danger of nuclear war is today much greater than it was in the late 1980s.

After thirty years of major reductions in nuclear arsenals to strengthen strategic stability, why are Russia and the United States further diverging in their understandings of the principles of stability? For what reasons, after so many years of joint efforts by the two powers to eliminate incentives for a nuclear first strike against the other, is such a scenario more likely today than at any point over the past thirty years? How is it that, after three decades of successful negotiations on the reduction and non-proliferation of nuclear weapons, the world is entering a period of disintegration when it comes to the entire system of control over these weapons? And, finally, why is the world entering a new cycle of nuclear and related arms races that is both multifaceted and multilateral?

In recent literature, much attention has been paid to factors that affect nuclear deterrence and stability from the outside: new missile defence systems, non-nuclear (conventional) high-precision long-range weapons, the influence of third and threshold nuclear states, space weapons, and-more recently-cyber threats. ${ }^{1}$ These new factors have pushed the core of nuclear deterrence-strategic relations between Russia and the United States - to the background in the public consciousness. Yet dangerous changes are taking place. This article examines the real and imaginary causes of the current situation and suggests potential ways to reduce tensions that could benefit international security.

\subsection{The Genesis of Nuclear Deterrence}

The philosophy of nuclear deterrence was born out of the symbiosis of the principle of military deterrence and the emergence of nuclear weapons. The first has thousands of years of history behind it. The latter appeared only in 1945. Intimidating an enemy with the threat of military force - to keep it from pursuing unacceptable actions or to force it into desired behaviour - has long been considered a political and psychological function of armies and fleets before they enter into combat actions. Two and a half millennia ago, the Chinese founder of strategic military thinking, Sun Tzu, wrote: "To fight and conquer in all your battles is not supreme excellence; supreme excellence consists in breaking the enemy's resistance without fighting. ... Therefore the skilful leader subdues the enemy's troops without any fighting. . . . With his forces intact he will dispute the mastery of the Empire, and thus, without losing a man, his triumph will be complete."2

The creation and use of the atomic bomb in 1945 did not immediately give rise to the idea of nuclear deterrence. At first, nuclear weapons were seen only as a new means of warfare, albeit one with unprecedented destructive power. According to

\footnotetext{
${ }^{1}$ As a recent example, see: Dvorkin 2018.

${ }^{2}$ Tzu 2019.
} 
official U.S. doctrine of "Massive retaliation" in the 1950s, the actual plan for the use of nuclear weapons - set out in the Pentagon's first Single Integrated Operational Plan, or SIOP-62 - called for quickly following any armed conflict with the Soviet Union by launching massive air strikes, conducted by 1,850 heavy and medium bombers that would drop 4,700 atomic and hydrogen bombs on cities and military installations across the Soviet Union, China, and their allies. $^{3}$ According to the Pentagon, this attack would have resulted in 800 million casualties across the targeted and adjacent neutral countries. ${ }^{4}$ That figure was no less than one-third of the global population at the time.

The creation of Soviet nuclear weapons and intercontinental bombers - and later missiles, as delivery means - deprived the United States of its traditional territorial immunity behind two oceans, and forced the two sides to seriously reconsider their views on the relationship between the political and military roles of nuclear weapons. The idea of nuclear deterrence came to the forefront of U.S. military policy. Of course, it was based on real nuclear forces and operational plans for their use. This qualitative shift laid the foundation for formulating the philosophy that nuclear weapons play a predominantly political role, rather than a military one. At the same time, both roles demonstrate the classic law of Hegel's dialectics on the unity and struggle of opposites (more on this below).

\subsection{The Birth of the Concept of Strategic Stability}

The origins of this concept lie in analytical developments of the late 1950s at the RAND Corporation. Its first author at the official level was Robert McNamara, who served as U.S. secretary of defense from 1961 to 1968. In 1967, in a sensational speech in San Francisco, he said: "We do not want a nuclear arms race with the Soviet Union, primarily because the action-reaction phenomenon makes it foolish and futile. . . . Both of our nations would benefit from a properly safeguarded agreement first to limit, and later to reduce, both our offensive and defensive strategic nuclear forces." $"$ This logic was implemented a few years later in the 1972 Anti-Ballistic Missile (ABM) Treaty and the Strategic Arms Limitations Treaty (SALT I). These agreements did not stop the arms race, however. It was only constrained, but gained momentum in other areas of the nuclear balance and types of nuclear weapons.

The number of U.S. nuclear weapons peaked in the early 1960 s at 32,000 , before being reduced to 22,200 weapons with a total 20,000 megatons of destructive power by 1989 . In the Soviet Union, by the end of the 1980s, the number of weapons reached a maximum of 30,000 with a total destructive potential of 35,000

\footnotetext{
${ }^{3}$ Kaplan 1983.

${ }^{4}$ Ellsberg 2017.

${ }^{5}$ McNamara 1968, pp. 61-62.
} 
megatons. Together, the two superpowers-which accounted for approximately 98\% of the global nuclear arsenal-had accumulated a destructive power equivalent to about 3 million Hiroshima-class bombs. But by the end of the 1980s, the Cold War was winding down, major changes were beginning to take place within the Soviet Union, and the absurd redundancies of accumulated nuclear capabilities became obvious to the ruling elite on both sides. That created a powerful impetus for negotiations on the deep reduction of nuclear weapons, culminating in radical treaties, such as the INF Treaty in 1987 and the first Strategic Arms Reduction Treaty (START 1) in 1991. Against this favourable backdrop, the concept of strategic stability became a legal norm.

That concept was formally invoked for the first and, unfortunately, last time in June 1990 in the Soviet-United States Joint Statement on Future Negotiations on Nuclear and Space Arms and Further Enhancing Strategic Stability. ${ }^{6}$ The concept was defined as a strategic relationship that eliminates the "incentives for a first nuclear strike". To create this kind of relationship, future agreements on strategic arms limitations were to include a number of agreed-upon elements:

- "the relationship between strategic offensive and defensive arms" (so that defences cannot undermine the other side's ability to retaliate);

- "measures that reduce the concentration of warheads on strategic delivery vehicles" (so one missile armed with several warheads could not hit several enemy missiles at their bases carrying a much larger number of warheads); and

- "giving priority to highly survivable systems" (so that they cannot be destroyed before launching a retaliatory strike).

This concept radically revised conventional wisdom. During the Cold War, each side ideologically perceived the enemy as an imminent aggressor, regardless of the specific content of its military doctrine or composition of its weapons arsenals. Now, both sides subscribed to the premise that a first nuclear strike is an act of aggression, no matter which state committed it. The basic assumption was that the goal of a first strike was to prevent or substantially weaken the retaliatory potential of the enemy by defeating its strategic forces at their starting positions, and to mitigate the impact of surviving weapons with ballistic missile defences (BMD). Strategic nuclear forces were therefore excluded, ${ }^{7}$ by default, from the military theorist Carl von Clausewitz's immortal formulation, "War is the continuation of politics by other means." 8 According to the logic of the 1990 Joint Statement, if neither party is able to significantly reduce the damage of the other's retaliatory strike by launching a first strike, then the outbreak of war (the first strike) will not

\footnotetext{
${ }^{6}$ Soviet-United States Joint Statement on Future Negotiations on Nuclear and Space Arms and Further Enhancing Strategic Stability 1990.

${ }^{7}$ For the purposes of this work, the term "strategic nuclear forces" is used almost as a synonym of the term "strategic arms", although in the future there may be a discrepancy due to the development of strategic arms with non-nuclear warheads.

${ }^{8}$ Von Clausewitz n.d..
} 
be a continuation of politics by other means, even in the event of an acute conflict of interest between the two states.

It is important to emphasize that the content of strategic stability was agreed upon during the negotiations for START I, signed in 1991, the complex provisions of which embodied all the principles of this concept. These were subsequently reflected in the 1993 START II, the 1997 START III Framework Agreement, the 2002 Strategic Offensive Reductions Treaty (SORT), and New START. As major parallel measures, deep parallel reductions were conducted regarding tactical nuclear arms, negotiations to conclude a treaty banning the production of fissile materials for military purposes (Fissile Material Cut-off Treaty) began in 1993, and the Comprehensive Nuclear-Test-Ban Treaty (CTBT) was signed in 1996. As a result of the implementation of these agreements, today's strategic balance looks much more stable (according to the criteria agreed upon in 1990) than on the eve of the 1990s, that is, before the signing of START I. The permitted levels of strategic weapons have been reduced about six-fold for warheads, almost threefold for deployed delivery systems, and by about thirtyfold for total mega tonnage. ${ }^{9}$ The ratio of warheads to delivery systems has decreased from $5: 1$ to $2: 1$. The share of arms with increased survivability, ${ }^{10}$ which once stood at $30-40 \%$, now amounts to $60-70 \%$ of the Russian and U.S. strategic nuclear arsenals.

Even more importantly, the strategic balance has become much more stable in substance - in terms of its 1990 definition, that is, the elimination of incentives for a nuclear first strike. Models of a hypothetical nuclear exchange show that, under realistic conditions, an attack by either party is not capable of destroying more than $50 \%$ of the other side's forces while employing $20 \%$ more weapons than are hit. ${ }^{11}$ In other words, an aggressor would disarm himself in a first strike, and the party under attack would have more surviving nuclear forces than the aggressor has in reserve after the strike, and could strike back, depriving the initiator of the desired advantage of the first strike. Nevertheless, strategic stability as one of the models of mutual nuclear deterrence is now deteriorating due to the evolution of strategic concepts and operational plans on both sides, as well as the beginning of a large-scale cycle of nuclear and advanced conventional arms races. These processes are naturally exacerbated by what is essentially a new Cold War between Russia and the West, which has accelerated the collapse of nuclear arms control.

\footnotetext{
${ }^{9}$ SIPRI 1991, 2017, pp. 3-51.

${ }^{10}$ Highly survivable capabilities refer to missile forces at sea and land-based mobile launchers. Heavy bombers in this case are not taken into account, since they are not kept in a state of high combat readiness, have a long flight time, and are not guaranteed to break through enemy air defenses.

${ }^{11}$ Dvorkin 2017, pp. 54-74.
} 


\subsection{Modern Nuclear Doctrines}

The role of nuclear weapons in Russia's foreign and military policy has increased markedly since 2011, following the ratification of New START and the failure of dialogue between the United States and Russia on the joint development of missile defence systems. Ahead of his victory in Russia's 2012 presidential election, Vladimir Putin stressed: "Under no circumstances will we give up the potential of strategic deterrence, and we will strengthen it. . . . So long as the 'powder' of our strategic nuclear forces, created by the great effort of our fathers and grandfathers, remains 'dry', no one will dare unleash large-scale aggression against us." ${ }^{12}$ This policy implied the large program of modernizing strategic nuclear forces, including the deployment of 400 new intercontinental ballistic missiles and the construction of eight nuclear-powered ballistic missile submarines. ${ }^{13}$

Meanwhile, U.S. President Donald Trump said in 2017: "Let it be an arms race. . . We will outmatch them at every pass and outlast them all."14 The position of the current U.S. political and military leadership on all aspects of nuclear deterrence is laid out quite clearly in the Nuclear Posture Review, published in January 2018. It is immediately apparent that in its basic assumptions, this policy is in tune with the Russian approach: "A safe, secure, and effective nuclear deterrent is there to ensure that a war can never be won and it will never occur."15 But the analogies do not end there. Both powers embrace not only retaliatory strikes in the event of an attack using nuclear weapons, but also their first use in response to an attack using conventional forces, as well as in some other situations.

The 2018 Nuclear Posture Review emphasizes: "Given the diverse threats and profound uncertainties of the current and future threat environment, U.S. nuclear forces play the following critical roles in U.S. national security strategy. They contribute to the deterrence of nuclear and non-nuclear attack; assurance of allies and partners; achievement of U.S. objectives if deterrence fails; and capacity to hedge against an uncertain future." 16 The Russian military doctrine, published in 2014, also calls for "permanent readiness of the Armed Forces, other troops, and bodies for deterring and preventing military conflicts and for armed defence of the Russian Federation and its allies in accordance with the norms of international law and international treaties of the Russian Federation." ${ }^{17}$ Nuclear forces should "maintain global and regional stability and the nuclear deterrence potential at a sufficient level."

In the event of war, the doctrine provides not only for a retaliatory nuclear strike, but also for a first strike: "The Russian Federation shall reserve the right to use

\footnotetext{
${ }^{12}$ Putin 2012.

${ }^{13}$ Ibid.

${ }^{14}$ Pilkington and Pengelly 2016.

${ }^{15}$ Office of the Secretary of Defense 2018.

${ }^{16} \mathrm{Ibid}$.

${ }^{17}$ Military Doctrine of the Russian Federation n.d..
} 
nuclear weapons in response to the use of nuclear and other types of weapons of mass destruction against it and/or its allies, as well as in the event of aggression against the Russian Federation with the use of conventional weapons when the very existence of the state is in jeopardy" (emphasis added). The purpose of a nuclear strike is defined as "the infliction of the assigned level of damage on an aggressor under any conditions." ${ }^{18}$ It turns out, however, that the Russian military doctrine is highly flexible. Answering a journalist's question in Sochi in October 2018, Putin unexpectedly formulated the nuclear aspect of the Russian doctrine as follows:

Our nuclear weapons doctrine does not provide for a preventive strike. I would like to ask all of you and those who will later analyze and in one way or another interpret my every word here, to keep in mind that there is no provision for a preventive strike in our nuclear weapons doctrine. Our concept is based on a launch-on-warning strike.... This means that we are prepared and will use nuclear weapons only when we know for certain that some potential aggressor is attacking Russia, our territory. I am not revealing a secret if I say that we have created a system which is being upgraded all the time as needed — a missile attack early warning system. This system monitors the globe, warning about the launch of any strategic missile... and identifying the area from which it was launched. Second, the system tracks the trajectory of a missile flight. Third, it locates a nuclear warhead impact zone.

Only when we know for certain — and this takes a few seconds to understand - that Russia is being attacked will we deliver a counterstrike. . . . Of course, this amounts to a global catastrophe, but I would like to repeat that we cannot be the initiators of such a catastrophe because we have no provision for a preventive strike. . . Any aggressor should know that retaliation is inevitable, and they will be annihilated. And we as the victims of an aggression, we as martyrs, would go to paradise while they would simply perish because they wouldn't even have time to repent their sins." 19

Public attention focused mostly on that last, emotional phrase. The remaining, unnoticed part of Putin's statement, however, seems to have made a fundamental amendment to Russia's military doctrine: essentially, the declaration of no first use of nuclear weapons. This is something the Soviet Union declared in 1982 (though no one in the world took it seriously then) and that Russia abolished in 1993 (which everyone believed). Of the nine states that currently possess nuclear weapons, the only countries to have undertaken such a commitment are China (though few believe it) and India (though it has provided some reservations). It is not clear what happened to the provision of Russia's official military doctrine that claimed the right to the first use of nuclear weapons "in the event of aggression against the Russian Federation with the use of conventional weapons when the very existence of the state is in jeopardy." ${ }^{20}$ Moreover, the described launch-on-warning concept clearly does not apply to the use of tactical nuclear weapons-which Russia probably has more of than all the other countries in the world combined-by ground forces, the navy, air defence, and the air force. ${ }^{21}$

\footnotetext{
${ }^{18}$ Ibid.

${ }^{19}$ Kremlin 2018.

${ }^{20}$ Military Doctrine of the Russian Federation n.d..

${ }^{21}$ According to independent estimates, Russia has about 1,850 units of such nuclear weapons. See more: SIPRI 2017.
} 
Furthermore, although Putin referred to nuclear weapons in general, it is possible that the concept he outlined relates only to the use of strategic nuclear forces, and above all the silo-based strategic rocket forces. Otherwise, it is not clear why large investments have been made for many years in expensive, high-value systems such as ballistic missile submarines and land-based mobile ICBMs, which are primarily designed for the "deep second strike" (that is, a launch when there is no doubt about an attack and its initiator after nuclear weapons have been detonated on Russian territory). In any case, Putin said what he said, and all possible interpretations are the personal opinion of experts, not the official position of the supreme commander, especially since he called on "all of you and those who will later analyse and in one way or another interpret my every word here" to keep this statement in mind. Besides, Putin implicitly reaffirmed the conviction shared by the Soviet Union and the United States in the 1970s and 1980s that a nuclear war would be a catastrophe for humanity, and therefore it cannot be fought and won. In any case, the historic importance of the above statement depends on whether or not the next edition of the Russian military doctrine is amended accordingly.

In all other respects, compared to the period of former U.S. president Barack Obama's time in the White House, the views of the two leading powers on the significance of nuclear weapons have become noticeably more symmetrical. In the Obama years, Moscow had not expressed alarm over U.S. nuclear forces, but had consistently shown concern about U.S. non-nuclear missile defence programs and high-precision long-range conventional offensive systems. For its part, Washington had worried about Russian sub-strategic (tactical) nuclear weapons and general-purpose forces. Now the United States sees Russia's (as well as China's) growing strategic nuclear potential over the past decade as a major threat, and intends to respond to this with an extensive program of modernization and expansion. In turn, Russia has clearly shifted emphasis in recent years to its long-range high-precision conventional offensive weapons, which finally aroused U.S. concern in the 2018 Nuclear Posture Review. ${ }^{22}$

Historical analysis shows that strategic asymmetries have periodically created considerable difficulties for nuclear arms control negotiations. ${ }^{23}$ Conversely, nuclear symmetry - which began with the Soviet Union achieving parity with the United States in the 1970s and 1980s-has usually contributed to the progress of negotiations. However, the current symmetry of strategic capabilities and views on their importance does not guarantee a resumption of dialogue and reduction of the nuclear threat. This apparent paradox is explained by nuclear deterrence's nature as a special kind of military and political relationship between states.

\footnotetext{
${ }^{22}$ U.S. Nuclear Posture Review n.d..

${ }^{23}$ These asymmetries included forward-deployed U.S. nuclear forces in Eurasia; the predominant share of ground-based missiles, especially heavy types, in the Soviet strategic forces, and the seaand air-based components of the U.S. triad; and U.S. advances in long-range cruise missiles in the late 1970s, an attempt to create space-based missile defense in the early 1980s, and, recently, leadership in the development of defensive and offensive high-precision conventional long-range systems.
} 


\subsection{The Dichotomy of Nuclear Deterrence}

The dual nature of nuclear deterrence arises from the blurred distinction between the use of nuclear deterrence as a political tool to prevent war and the practical use of nuclear weapons as a means of warfare. After all, any deterrence is only feasible if it relies on the material basis of nuclear weapons and the willingness to use them in accordance with military doctrine, strategy, and operational plans. In today's world, all states openly (or, like Israel, by default) maintain and improve their nuclear weapons for deterrence purposes. At the same time, no weapons system is actually created for deterrence, because it is too general and amorphous a concept for the military planners and arms designers. The development of all nuclear weapons systems integrates the latest technical achievements to perform specific military tasks: the destruction of certain military and civilian targets in the specified conditions of conflict. At the same time, certain technical aspects of weapons and related operational plans may increase the likelihood of a military conflict or its escalation. Today, all of this is happening under the influence of technological and military developments and new strategic concepts among the leading nuclear powers, and is being exacerbated by the growing political tensions between Russia and the United States.

The enormous destructive power and technical complexity of existing nuclear forces have effectively left critical political decisions hostage to strategic concepts and operational plans developed in military offices long before an outbreak of armed conflict. And these plans are dictated by the technical specifications of the weapons and their command-and-control information systems. With regards to the present day, the classic Von Clausewitz postulate can be reformulated as follows: war (at least global nuclear war) is no longer the continuation of policy by other means. It is the continuation of military doctrine and the technical specifications of weapons systems that determine the plans and methods of their employment. An illustration of this is the concept of launch-on-warning as outlined by the Russian leadership. It is mainly driven by the vulnerability of strategic forces to a massive nuclear missile strike. However, this only relates to ICBMs in hardened silo launchers, underground command posts, missile submarines in bases, and bombers at airfields. Land-based mobile missiles on deployment routes, submarines at sea, and aircraft in the air are all able to survive nuclear attack and deliver a "deep second strike", but this potential seems to be considered insufficiently destructive.

The "assigned level of damage" mentioned in the Russian military doctrine therefore probably implies that a launch-on-warning of silo-based missiles must be carried out against the aggressor, in particular, launches of the most powerful heavy-class ICBMs (such as the current SS-18 Satan and its upcoming follow-on Sarmat). ${ }^{24}$ And this means that the technical specifications of weapons (such as the inability to make mobile heavy-class liquid-fuelled ICBMs, the hardness of their silos, as well as the number, yield, and flight time of the attacking warheads) would

\footnotetext{
${ }^{24}$ Military Doctrine of the Russian Federation n.d..
} 
dictate the decision of the state's leadership to end the world: to strike back before the arrival of nuclear attack, the consequences of which were so eloquently described in Putin's speech at Valdai. Meanwhile, the concept of launch-on-warning carries a fair risk of unintended nuclear war. This comes from the possibility of a technical failure of the missile attack warning system-which is composed of satellites and ground-based radars - or the unauthorized launch of missiles by the opponent, incorrect interpretations of the other side's actions, or an uncontrolled escalation of a crisis or local armed conflict.

In the short term, this risk may grow significantly along with the development of military hardware and changes to the strategic balance. For example, space weapons and cyber warfare are likely to have the ability to disable early warning systems or trigger false alarms. The proliferation of sea-based nuclear missiles poses the risk of provocative "anonymous" third-party attacks from underwater. The development of hypersonic systems will deprive ground-based radars of the ability to determine, in a timely manner, the trajectory of enemy missiles and their impact area, which means that a launch-on-warning response will have to be authorized immediately upon detection from satellites, which periodically signal false alarms.

Finally, the collapse of the INF Treaty and the possible deployment of new U.S. medium-range missiles in Europe and Asia will, due to their short flight time or low trajectory, neutralize the Russian concept of launch-on-warning, as there will simply be no time for its implementation during an attack. According to statements by authoritative military commanders, this might force Russia to accept the concept of a pre-emptive nuclear strike. ${ }^{25}$ It is clear that such a strike would be more destructive than a purely retaliatory strike, but in any case, the subsequent nuclear retaliation by the enemy would be fatal for Russia. And if the United States accepts the concept of a pre-emptive strike, any possible crisis situation would force both sides to speed ahead of the other: not for any political reasons, but because of the vulnerability of Russian strategic forces and command-and-control system to the first strike by the other side.

Another example of the self-destructive tendencies of nuclear deterrence is the concept of a limited or selective nuclear war. The perennial question that strategic planners have fought over for decades is what to do if nuclear deterrence fails. These scenarios include if an attack by an enemy using conventional weapons threatens imminent defeat (including destruction of nuclear forces in bases using high-precision non-nuclear capabilities), if the other side uses nuclear weapons in any kind of limited way, or if it uses other weapons of mass destruction or cyber-attacks. From the early 1970s, the United States - starting with then secretary of defence James Schlesinger-promoted the concept of "retargeting": various options for selective and limited strikes against Soviet military targets. ${ }^{26}$ But all of these plans were dashed by the likelihood of a massive nuclear response by the

\footnotetext{
${ }^{25}$ See more: interview with Colonel General Esin 2018.

${ }^{26}$ Schlesinger 1974.
} 
Soviet Union, which categorically rejected such ideas and strengthened the potential for a "devastating retaliation". ${ }^{27}$ Changes began many years later. In 2003, in an official Ministry of Defence document, Russia announced plans for the "de-escalation of aggression ... . [by] the threat to deliver or by the actual delivery of strikes of various intensity using conventional and (or) nuclear weapons." As such, the document assumed the possibility of "dosed combat employment of selected components of the Strategic Deterrence Force". 28

It should be noted that, since then, subsequent editions of Russian military doctrine and other official strategic documents have made no mention of such concepts. At the same time, the adopted doctrinal formulations do not exclude such actions, since they do not specify how Russia can "use nuclear weapons . . . in the event of aggression against the Russian Federation with the use of conventional weapons when the very existence of the state is in jeopardy". ${ }^{29}$ Neither is it clear when and how exactly the existence of the state can be considered in jeopardy, and what level of damage to the enemy is interpreted as sufficient. ${ }^{30}$ The United States is not transparent about these points either, but officially allows for the possibility of a limited nuclear war.

Amid the current escalation of tensions, politicians and military experts in Russia and the West have renewed their focus on this concept. A number of publications by Russian military specialists (in active service) justify

\section{the limited nature of a first nuclear strike, which is designed not to harden, but rather to sober up an aggressor, to force it to halt its attack and move to negotiations. In the absence of the desired reaction, provision is made for increasing the mass of nuclear weapons brought to bear, both in quantitative terms as well as their energy emission (that is, destructive power). Therefore ... a nuclear first strike by the Russian Federation could have a limited character. ${ }^{31}$}

However, in his address to the Federation Council on 1 March 2018, Putin said: "Any use of nuclear weapons against Russia or its allies, weapons of small, medium, or any yield at all, will be considered as a nuclear attack on this country. Retaliation will be immediate, with all the attendant consequences. ${ }^{32}$ Implicitly, this may mean that a limited nuclear war is not envisioned in Russian doctrine and planning either, but this important issue might benefit from an unequivocal official clarification.

The United States has included the concept of a limited nuclear war in its nuclear doctrine for many years in the form of "tailored nuclear options". But in the 2018 Nuclear Posture Review, this topic took on a central role and became the main innovation of Trump's nuclear strategy. The review states:

\footnotetext{
${ }^{27}$ Ogarkov 1982.

${ }^{28}$ Current Goals in the Development of the Armed Forces of the Russian Federation 2003.

${ }^{29}$ Military Doctrine of the Russian Federation n.d..

${ }^{30}$ Ibid.

${ }^{31}$ Akhmerov et al. 2016.

${ }^{32}$ Presidential Address to the Federal Assembly 2018.
} 
Recent Russian statements on this evolving nuclear weapons doctrine appear to lower the threshold for Moscow's first use of nuclear weapons. Russia demonstrates its perception of the advantage these systems provide through numerous exercises and statements. Correcting this mistaken Russian perception is a strategic imperative. ... To address these types of challenges and preserve deterrence stability, the United States will enhance the flexibility and range of its tailored deterrence options. ${ }^{33}$

For limited nuclear strikes, the plan is to equip part of the Trident-2 submarine-launched ballistic missiles (SLBMs) with low-yield warheads, as well as to develop long-range standoff (LRSO) air-launched missiles, guided bombs with variable yields (such as the B-61-12) for tactical and strategic bombers, and new sea-launched cruise missiles with nuclear warheads. ${ }^{34}$ No matter how much the deterrence doctrine is used to justify such capabilities and proposals, they actually reduce the nuclear threshold and increase the likelihood of any armed clash between the superpowers escalating into a nuclear conflict with a subsequent exchange of mass nuclear strikes.

Another controversial response to the question of what to do in the event that deterrence fails is the concept of damage limitation in a nuclear war. The recent U.S. Nuclear Posture Review says: "The goal of limiting damage if deterrence fails in a regional contingency calls for robust adaptive planning to defeat and defend against attacks, including missile defence and capabilities to locate, track, and target mobile systems of regional adversaries." 35 Although this passage refers to regional adversaries, Russia sees itself as a target of these plans (likewise, it feels threatened by U.S. missile defences and long-range high-precision conventional weapons). In a nuclear war, the desire to limit damage to one side by offensive operations looks like a threat of disarming strike to the opposite side, especially when it comes to destroying Russia's highly survivable forces, which in the form of mobile ICBMs are associated mainly with the concept of "deep second strike"-the basis of the philosophy of strategic stability.

Another dangerous area in which the degradation of nuclear deterrence is happening is the development of a variety of long-range (over $500 \mathrm{~km}$ ) strike systems capable of delivering conventional warheads to targets that could previously only be destroyed with nuclear weapons. This has been made possible by new command-and-control information systems (including in space) and the miniaturization of electronics, which can significantly improve the accuracy of the guidance systems (allowing down to several meters of circular error probability). ${ }^{36}$ Existing

\footnotetext{
${ }^{33}$ Nuclear Posture Review n.d..

${ }^{34}$ Ibid.

${ }^{35}$ Ibid.

${ }^{36}$ This applies to U.S. systems such as the Tomahawk sea-launched cruise missile (BGM-109), and air-launched cruise missiles (AGM-84, AGM-158B, JASSM-ER). Russia is also increasing its arsenal of non-nuclear cruise missiles: Kalibr 3M-54 and 3M-14 sea-launched cruise missiles and the Kh-55SM, Kh-555, and Kh-101-type air-launched cruise missiles. By 2018, the number of high-precision cruise missiles in the Russian arsenal had increased more than thirtyfold, according to the presidential address to the Federal Assembly on 1 March 2018.
} 
non-nuclear cruise missiles have a relatively limited range (less than 2,000 km), subsonic speeds, and a long flight time to targets (about two hours). Yet the next generation of high-precision hypersonic or ballistic conventional weapons under development will make it possible to deliver these kinds of strikes at intercontinental ranges (over $5,500 \mathrm{~km}$ ) with a relatively short flight time (up to $60 \mathrm{~min}$ ). ${ }^{37}$

Non-nuclear long-range conventional systems are designed for and used by the superpowers primarily in regional wars (Iraq, the Balkans, Afghanistan, Libya, and Syria). However, they impinge on the strategic balance through the concept of "conventional deterrence", which has long been proclaimed in official U.S. documents, ${ }^{38}$ and since 2014 , in the Russian military doctrine, which states that: "The use of high-precision weapons is envisaged by the Russian Federation within the framework of performing strategic deterrence use-of-force measures." 39 Initially, this concept was conceived as the preferred alternative to a reliance on nuclear weapons and a way of raising the nuclear threshold. But, in fact, the opposite has turned out to be true: it results in lowering of the threshold. The issue of whether the accuracy of these capabilities will be sufficient to destroy hardened targets (ICBM silos and underground command posts) and whether they will be able to destroy ground-mobile missiles remains highly uncertain. However, there is no doubt that non-hardened strategic nuclear facilities are vulnerable even to existing subsonic non-nuclear cruise missiles. These include missile and air defence radars, light mobile ICBM shelters, submarines in port, bombers at base, forward nuclear warhead depots, and spacecraft control stations. These objects could be hit even in the event of a regional conflict between Russia and NATO.

In addition, many current and future weapons of this kind, as well as their launchers, are dual-purpose, and their character until the moment of detonation will be indistinguishable from a nuclear strike. This applies to heavy and medium bombers, tactical strike aircraft with missiles and bombs, ships, and attack submarines with missiles capable of carrying both nuclear and conventional warheads: the Kalibr and Tomahawk sea-based cruise missiles, ${ }^{40}$ air-launched cruise missiles of the Kh101/102 type or the AGM-158, and Iskander-type ground-launched tactical ballistic and cruise missiles. Such systems and associated operational plans could also trigger the rapid, uncontrolled escalation of a conventional local conflict or even a military incident into nuclear war.

\footnotetext{
${ }^{37}$ In particular, such systems are being developed by the United States as part of the Prompt Global Strike program, for example, the Alternate Reentry System (ARS). In parallel, the Boeing X-51A Waverider hypersonic air-launched cruise missile is being tested for deployment on heavy bombers. Russia is ahead of the United States in flight tests of hypersonic gliders for launch by ICBMs (such as the SS-19 or the new Sarmat heavy ICBM by 2020). Putin spoke about the new Avangard system during his 1 March 2018 address.

${ }^{38}$ Einhorn and Pifer 2017.

${ }^{39}$ Military Doctrine of the Russian Federation n.d..

${ }^{40}$ In 2010, the U.S. decided to withdraw the Tomahawk from nuclear service by 2014, but the 2018 Nuclear Posture Review announced the decision to return the SLCM to nuclear service aboard submarines.
} 
Neither Russia nor the United States — nor their allies — want war, and they have no real political motives to unleash it. But it should be remembered that in many wars, both sides believed that they were only defending themselves, fighting off real or probable aggression, even if it was they themselves that carried out offensive operations. That is how World War I began in 1914. That conflict shaped the follow-on terrible history of the twentieth century, and its consequences are still playing out across the world, including in Russia. The Cuban Missile Crisis of 1962 demonstrated clearly that a nuclear war could begin because of a loss of control over events, not as the result of planned aggression. Similar, though less dangerous, cases occurred during the Berlin crisis of 1961 and during three Middle East wars in 1956, 1967, and 1973, among a number of other similar situations. Since the events of 2014 in Ukraine, intense military confrontation between Russia and NATO has been renewed in Eastern Europe, the Baltic and Black Seas, and the Arctic. Regular large-scale military exercises (including with the participation of strategic systems and the imitation of nuclear weapon use) are frequent demonstrations of force. ${ }^{41}$ Dangerous close encounters of combat ships and aircraft are a common occurrence. The possibility of a major war between Russia and NATO, which seemed irrevocably consigned to the past just a few years ago, hangs over Europe and the world.

\subsection{The Collapse of Nuclear Arms Control}

The military, technical, strategic, and political trends discussed above are destroying the systems and regimes of nuclear arms control built over a half-century through the great efforts of the Soviet Union/Russia, the United States, and others. Scholars have warned about this scenario for years, ${ }^{42}$ and now the danger has become obvious to everyone. It is clear now that the weakest link in the nuclear arms control system is the INF Treaty. At the same time, the main claims of the parties against each other on compliance issues could be solved relatively quickly at the technical level if there was the political will and strategic interest in solving them. But instead, the Trump administration has officially announced its intention to denounce this historic treaty.

The crisis in nuclear arms control is also manifested in the fact that for eight years, Russia and the United States have not discussed how to progress to the next START agreement. This is the longest pause in fifty years for such negotiations. Although both parties fulfilled their reduction obligations under the current New START by the February 2018 deadline (though with certain misgivings from Russia), the treaty will expire in 2021, and this will create a vacuum in strategic arms control. There is little time for the conclusion of a new treaty, given the deep disagreement between the two parties on important issues. Meanwhile, the U.S. administration has been

\footnotetext{
${ }^{41}$ Unified Information Portal 2011.

${ }^{42}$ Arbatov 2015.
} 
reluctant to extend New START to 2026 (which can be done once under the terms of the treaty) and faces resistance from Congress on such a step.

The United States and Russia are therefore on the threshold of a new large-scale arms race and, unlike the Cold War, this nuclear missile race will be augmented by competition in offensive and defensive non-nuclear strategic and medium-range weapons, as well as rivalry in the development of space weapons and cyber warfare. Beginning in the mid-2020s, the United States plans to modernize its strategic triad: new systems to replace the current heavy bombers, ICBMs, and SLBMs. ${ }^{43}$ And Russia continues to modernize its triad, deploying and developing two new ICBM systems (Yars and Sarmat), one SLBM system (Borei-Bulava), and two heavy bomber systems (Tu-160M and PAK DA). In addition, the United States is developing the above-mentioned systems for limited nuclear strikes (Trident-2 SLBMs with low-yield warheads, LRSO, B-61-12, and nuclear sea-based cruise missiles). And Russia is developing the strategic systems unveiled in Putin's 1 March 2018 address (that is, Burevestnik nuclear-powered intercontinental cruise missiles, Avangard hypersonic gliders, and Poseidon long-range nuclear super-torpedoes). ${ }^{44}$ The impact of these weapons on strategic stability requires special analysis, but is unlikely to be positive.

In addition, this arms race will be multilateral, involving states such as China, NATO members, India and Pakistan, North and South Korea, Japan, and others. The start of a nuclear arms race would undoubtedly undermine the norms and regimes for the non-proliferation of nuclear weapons. The review conference of the Non-Proliferation Treaty in 2015 ended in failure, and there is a high probability that the same will happen at the next conference in 2020, especially in light of the U.S. withdrawal from the 2015 multilateral Iran nuclear deal. This will likely be followed by the collapse of the CTBT, which for twenty-three years has not entered into force because of the refusal of the United States and a number of other states to ratify it. Nor is there much hope for progress in negotiating the Fissile Material Cutoff Treaty, which has been stalled for more than a quarter-century. Iran and Saudi Arabia will likely join the nuclear club, as may Egypt, Turkey, Japan, South Korea, Taiwan, Nigeria, Brazil, and other countries. Through them, nuclear weapons will sooner or later inevitably fall into the hands of international terrorists, with all the ensuing consequences.

\subsection{Renewing Strategic Stability and Arms Control}

At the Valdai forum in Sochi in 2016, Putin said "nuclear weapons are for deterrence and a factor of ensuring peace and security worldwide," and cannot be considered "a factor of any potential aggression." 45 As can be seen from the above

\footnotetext{
${ }^{43}$ U.S. Nuclear Posture Review n.d..

${ }^{44}$ Presidential Address to the Federal Assembly 2018.

${ }^{45}$ Valdai International Discussion Club 2016.
} 
analysis, nuclear deterrence can serve as a pillar of international security with one crucial reservation: namely, that it can only work in conjunction with negotiations and agreements on the limitation, reduction, and non-proliferation of nuclear weapons. Without such checks, nuclear deterrence goes berserk. It endlessly fuels the arms race, brings the great powers to the brink of nuclear war in any serious crisis, and sometimes the very dynamics of nuclear deterrence can instigate confrontation.

By the early 1960s, the world had gone through a series of increasingly dangerous crises, edging closer to the brink of nuclear war. The culmination was the 1962 Cuban Missile Crisis, when sheer luck saved humanity from disaster. Only after that, with the conclusion of the Partial Test Ban Treaty in 1963, did the construction of a legal, treaty-based system of control over nuclear arms begin. A few years ago, the world once again embarked on the pernicious path of confrontation and military competition, as all areas of arms control stalled for technical, strategic, and political reasons. Only through the strengthening of strategic stability, rehabilitation, and improvement of the nuclear arms control system can we turn away from the path to the nuclear brink.

The Soviet-U.S. concept of strategic stability agreed upon in 1990 was perhaps even more revolutionary than the authors themselves understood. ${ }^{46}$ It stipulated that the two sides recognized each other's right to a nuclear strike capability as a guarantor of their own security, but undertook not to develop offensive and defensive weapons that would deprive the other party of such an insurance. Moreover, the limitation of damage from a hypothetical nuclear war should not be carried out by developing disarming strike capabilities, large-scale anti-missile defences, and options for the selective use of nuclear weapons. Instead, it had to be achieved through minimizing the likelihood of such a war politically and reducing the destructive arsenals through treaties, transparency, and confidence-building measures, as well as improving mutual understanding of military doctrines and concepts.

Such a policy is not possible if the powers independently develop concepts, operational plans, and deterrence capabilities, since those are always aimed at defeating the alleged enemy "if deterrence fails". As stated in the Russian military doctrine, in an analogy to U.S. strategic documents and those published by other states, the purpose of the armed forces is "defeating the aggressor's troops (forces) and forcing the aggressor to cease hostilities on terms and conditions suiting the interests of the Russian Federation and its allies" ${ }^{47}$ However, deterrence in a crisis may collapse simply under the weight of plans and capabilities intended to deter the enemy. Responsibility for the decision to launch a nuclear strike is laid by the military at the feet of politicians, but those politicians are hostage to the operational plans and technical characteristics of weapons developed by the military and engineers.

\footnotetext{
${ }^{46}$ At least, this pertains to the author as a participant of those negotiations.

${ }^{47}$ Military Doctrine of the Russian Federation n.d..
} 
Only an understanding of strategic stability that is agreed upon by both sides and embodied in arms limitation and reduction agreements can put strict limits on destabilizing concepts, plans, and arms of nuclear deterrence. Elements of this philosophy were enshrined in the 1990 strategic stability document Now, as then, the conditions of strategic stability can only be imagined between Russia and the United States if this concept is to have clear meaning (elimination of incentives for a nuclear first strike) rather than stand as wishful thinking for international peace and harmony. However, after nearly thirty years, it would be crucial to update the agreed principles of strategic stability in light of the changes that have taken place.

Moreover, the very definition of stability in Russian-U.S. strategic relations should be expanded to include not only "eliminating incentives for a nuclear first strike" but also "incentives for any use of nuclear weapons". With regard to deterring a conventional attack, it should be based on sufficient general-purpose forces and capabilities and, better still, on agreements such as the Conventional Armed Forces in Europe (CFE) Treaty (1990). Further to that point, the meaning of the provision on "measures that reduce the concentration of warheads on strategic delivery vehicles" and "giving priority to highly survivable systems" should be expressed not indirectly but directly, and with mutual recognition that weapons systems threatening the survival of strategic forces and their command-and-control are destabilizing and should be limited and reduced as a matter of priority. If this condition is met, launch-on-warning concepts should be mutually cancelled in light of the possibility of initiating nuclear war due to false alarms, unauthorized use, or cyber sabotage.

In addition, weapons systems that blur the line between nuclear and conventional arms (that is, dual-purpose) should be recognized as destabilizing and should be subject to mutual restrictions and confidence-building measures. Missile defence systems intended to protect against third countries and non-state actors should once again be the subject of a mutually agreed "relationship between strategic offensive and defensive arms". Space weapons - above all, anti-satellite systems - should be acknowledged as destabilizing and be subject to a verifiable ban. Cyber warfare against each other's strategic command-and-control information systems is also destabilizing and should be subject to prohibitions and confidence-building measures. Both sides should recognize that their nuclear doctrines and weapons could create the risk of unintended war as the result of an escalating crisis, which should be the subject of serious and ongoing dialogue at the state level. Finally, the involvement of third states in the process of nuclear arms limitation should be based on an objective assessment of their forces and programs and on an agreement on the sequence, principles, and objects of multilateral arms limitation agreements.

It is extremely important to note that the abstract discussion of the modern meaning of strategic stability will remain fruitless, as demonstrated by years of dialogue on this topic between the United States and China, ${ }^{48}$ as well as between

\footnotetext{
${ }^{48}$ It is true, however, that the United States and China have made some progress: they have begun to compile a dictionary of strategic words and concepts.
} 
Russia and the United States. The proposals that have emerged in recent years for multilateral discussions on nuclear issues and strategic stability as an alternative to specific negotiations do not provide a clear answer to the direct questions of format, subject, and expected results of such intellectual exercises. ${ }^{49}$ Such ideas are no doubt attractive to those military and political leaders who are prejudiced against nuclear arms control agreements, do not understand their importance, and do not know the history of the issue. In reality, however, the alternative to time-consuming and sometimes exhausting negotiations is not strategic discussion in the "clubs of interested parties", but an unrestricted arms race for all, at great cost and with the growing danger of war.

Another extreme was the approval of the Treaty on the Prohibition of Nuclear Weapons (TPNW) by the UN General Assembly on 6 July $2017 .{ }^{50}$ Without calling into question the good intentions of supporters of this treaty, it must be admitted that the treaty is completely unrealistic, both in theory and in practice, if only because all nine of the nuclear powers that would have to ratify it, in a rare act of solidarity, did not support the UN initiative. But along with the many technical and economic shortcomings of this project, the main omission in the treaty is that it does not address the military and political roles that states associate with nuclear weapons, besides deterrence of nuclear attack: preventing conventional aggression or attacks with other types of WMDs and systems based on new physical principles; maintaining international prestige and status (especially if economic and political assets are lacking); providing security guarantees to allies living near strong opponents; obtaining a bargaining chip for negotiations on other issues; and so on. Over the past seventy years, nuclear weapons have become an integral part of international politics, military strategy, and security. Without changing this environment, it is impossible to simply excise the nuclear factor as a malicious entity from international relations: the system would turn into chaos and the existing security norms and institutions would collapse.

Only consistent and step-by-step treatment is applicable: disarmament measures, in parallel with positive changes in the international political and strategic environment. And it is only in the context of substantive negotiations on arms limitations, reduction, and prohibition that these updated principles of stability can be formulated. The first priority is to salvage the INF Treaty. Russia and the United States should work together to develop additional means of verification, using confidence-building measures and on-site inspections, in order to eliminate mutual suspicions. Technical solutions have been around for several years, ${ }^{51}$ and only the ambiguous attitude of the parties toward this agreement - and the overall negative atmosphere in their relations - have prevented them from sorting out these disagreements. If the treaty is nevertheless abrogated, the two powers should as a

\footnotetext{
${ }^{49}$ For more, see: Karaganov 2017.

${ }^{50} \mathrm{UN} 2017$.

${ }^{51}$ Arbatov 2018.
} 
minimum make a commitment not to deploy missiles prohibited by the agreement on the European continent, and agree on appropriate transparency measures.

Then, if New START cannot be extended beyond 2021, there is an urgent need to begin negotiations on a follow-on treaty. Ceilings on the maximum number of launchers and warheads are not so important; they can be lowered marginally, even by just 100-200 launchers and warheads. What is far more important is the scope of the next agreement. It is essential that any follow-on treaty should count air-launched nuclear cruise missiles and bombs according to the actual loading of the bombers, and include ground-based intercontinental cruise missiles under overall ceilings, as well as intercontinental hypersonic systems, regardless of the type of warheads - nuclear or conventional - that they carry.

Restrictions or bans on fractionally orbital ICBMs and long-range autonomous underwater drones could be exchanged for measures of transparency and delineation of missile defence systems. For example, the sides could limit (to mutually acceptable parameters) strategic defence from ICBMs and SLBMs but allow regional missile defence and air defence systems for protection against mediumand short-range ballistic and cruise missiles. In parallel, negotiations on space weapons should be initiated, beginning with the prohibition of testing any anti-satellite systems against real orbital targets. It is also essential to move on to discussing a mutual pact not to develop capabilities and methods of cyber-attack against strategic command-and-control information systems. Concurrent with intensified negotiations on the issues of nuclear disarmament and the limitation of non-nuclear weapons systems, it might be possible to gradually and selectively include other states in this process. All of these measures are necessary to provide a foundation for the real intensification of cooperation between leading powers in the fight against the threat of nuclear terrorism, which will otherwise inevitably increase.

Amid the current deplorable political and strategic situation, it may seem that the above proposals are utopian. However, experience shows that the situation can change very quickly - both for the better and for the worse. To avoid the latter, every effort must be made to achieve the former. The main prerequisite is the recognition by political leaders and elites of the leading powers that the task of saving and updating the system and regimes of nuclear arms control is the top priority, just as the preceding generation saw it after the Cuban Missile Crisis. The dynamic changes in the world order, military technology, and strategic thinking do not mean that nuclear arms control is no longer needed. On the contrary, these changes make arms control an even more essential condition for the survival of human civilization than it was during the past Cold War. 


\section{References}

Akhmerov Y, Valeev M, Akhmerov D (2016) The Balloon Is a Friend of 'Sarmat'. Military-Industrial Courier (in Russian). https://vpk.name/news/165525_aerostat_drug_ sarmata.html (12 October 2016) Accessed 2 February 2018

Arbatov A (2015) Nuclear Arms Control: The End of the Story. Global Economy and International Relations, 5:5-18

Arbatov A (2018) The Danger of Withdrawing from the INF Treaty. Carnegie Moscow Center. https://carnegie.ru/commentary/77589 (23 October 2018)

Current Goals in the Development of the Armed Forces of the Russian Federation (2003) Red Star (in Russian). http://old.redstar.ru/2003/10/11_10/3_01.html (11 October 2003). Accessed 2 February 2018

Dvorkin V (2017) Reduction of Offensive Weapons. In: Arbatov A, Dvorkin V (eds) A Polycentric Nuclear World: Challenges and New Opportunities (in Russian). Carnegie Moscow Center; ROSSPEN, Moscow, pp 54-74

Dvorkin V (2018) Strategic Stability: Preserve or Destroy? (in Russian) (28 November 2018). Carnegie Moscow Center. https://carnegie.ru/2018/11/28/ru-pub-77809

Einhorn R, Pifer S (2017) Meeting U.S. Deterrence Requirements. Foreign Policy at Brookings, p 20

Ellsberg D (2017) The Doomsday Machine: Confessions of a Nuclear War Planner. Bloomsbury, New York, pp 100-104

Kaplan F (1983) The Wizards of Armageddon. Simon and Schuster, New York, p 269

Karaganov S (2017) On the New Nuclear World: How to Strengthen Deterrence and Maintain Peace. Russia in Global Politics 2

Kremlin (2018) Transcript of the meeting of the Valdai International Discussion Club (18 October 2018). http://kremlin.ru/events/president/news $/ 58848$

McNamara R S (1968) The Essence of Security: Reflections in Office. Harper and Row, New York, 61-62

Military Doctrine of the Russian Federation (in Russian). http://news.kremlin.ru/media/events/ files/41d527556bec8deb3530.pdf. Accessed 1 February 2018

Office of the Secretary of Defense (2018) U.S. Nuclear Posture Review (February 2018). Office of the Secretary of Defense, Washington, DC. https://media.defense.gov/2018/Feb/02/ 2001872886/-1/-1/1/2018-NUCLEAR-POSTURE-REVIEW-FINAL-

Ogarkov N (1982) Always Ready to Defend the Fatherland (in Russian), p 49

Pilkington E, Pengelly M (2016) Let It Be an Arms Race: Donald Trump Appears to Double Down on Nuclear Expansion, Guardian (24 December 2016). https://www.theguardian.com/ us-news/2016/dec/23/donald-trump-nuclear-weapons-arms-race. Accessed 21 February 2018

Presidential Address to the Federal Assembly (1 March 2018). http://en.kremlin.ru/events/ president/news $/ 56957$

Putin V (2012) Be Strong: Guarantees of Russian National Security. Rossiiskaya Gazeta (in Russian) (20 February 2012). http://www.rg.ru/2012/02/20/putin-armiya.html. Accessed 2 February 2018

Schlesinger J R (1974) Annual Defense Department Report, FY 1975 (4 March 1974). U.S. Government Printing Office, Washington DC. http:/history.defense.gov/Portals/70/ Documents/annual_reports/1975_DoD_AR.pdf?ver=2014-06-24-150705-323. Accessed 2 February 2018

Soviet-United States Joint Statement on Future Negotiations on Nuclear and Space Arms and Further Enhancing Strategic Stability (1990). https://www.presidency.ucsb.edu/node/263949 (1 June 1990). Accessed 11 February 2019

Stockholm International Peace Research Institute (SIPRI) (1991) SIPRI Yearbook 1990: World Armaments and Disarmament. Oxford University Press, Oxford, pp 3-51 
Stockholm International Peace Research Institute (SIPRI) (2017) SIPRI Yearbook 2017: Armaments, Disarmament, and International Security. Oxford University Press, Oxford

Tzu S (2019) The Art of War. http://classics.mit.edu/Tzu/artwar.html. Accessed 11 February 2019

UN (2017) Treaty on the Prohibition of Nuclear Weapons. http://undocs.org/en/A/CONF.229/ 2017/8. Accessed 11 February 2019

Unified Information Portal (2011) (in Russian) (17 December 2011) Russia Conducted Secret Military Exercises Near EU Borders-the Media. http://ua-ru.info/news/41846-rossiyaprovela-taynye-voennye-ucheniya-u-granic-es-smi.html. Accessed 2 February 2018

Valdai International Discussion Club (2016) (27 October 2016). http://en.kremlin.ru/events/ president/news/53151. Accessed 28 October 2018

U.S. Nuclear Posture Review (n.d.)

Von Clausewitz C (n.d.) On War, Part I, chapter 1, section 28

Alexey Arbatov is the head of the Center for International Security at the Primakov National Research Institute of World Economy and International Relations. Arbatov is a former scholar in residence and the chair of the Carnegie Moscow Center's Nonproliferation Program. A former member of the State Duma, vice chairman of the Russian United Democratic Party (Yabloko), and deputy chairman of the Duma Defence Committee, he is currently member of, i.a., the research council of the Russian Ministry of Foreign Affairs and of the governing board of the Stockholm International Peace Research Institute.

Open Access This chapter is licensed under the terms of the Creative Commons Attribution 4.0 International License (http://creativecommons.org/licenses/by/4.0/), which permits use, sharing, adaptation, distribution and reproduction in any medium or format, as long as you give appropriate credit to the original author(s) and the source, provide a link to the Creative Commons license and indicate if changes were made.

The images or other third party material in this chapter are included in the chapter's Creative Commons license, unless indicated otherwise in a credit line to the material. If material is not included in the chapter's Creative Commons license and your intended use is not permitted by statutory regulation or exceeds the permitted use, you will need to obtain permission directly from the copyright holder.

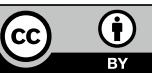

